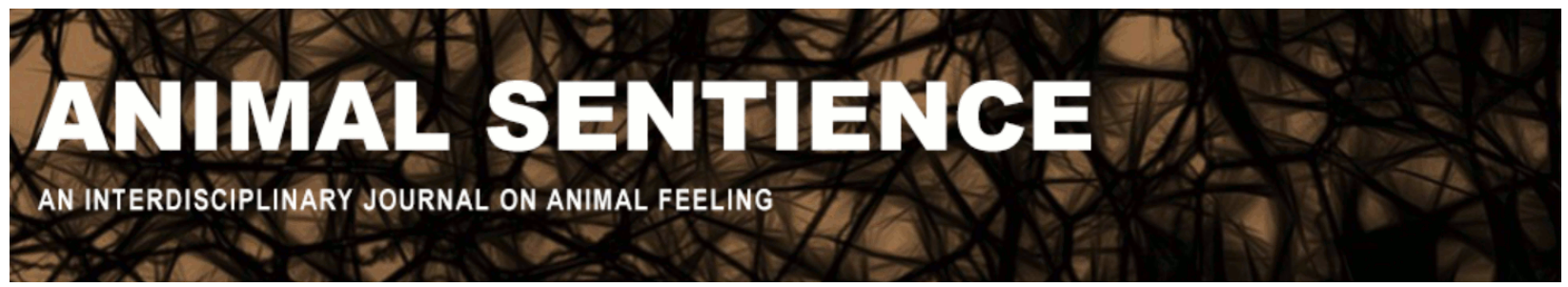

Meyers-Manor, Julia E. (2018) If it looks like a duck: Fish fit the criteria for pain perception. Animal Sentience 21(7)

DOI: $10.51291 / 2377-7478.1328$

Date of submission: 2018-05-18

Date of acceptance: 2018-05-22

(c)

This article has appeared in the journal Animal

Sentience, a peer-reviewed journal on animal

cognition and feeling. It has been made open access,

free for all, by WellBeing International and deposited

in the WBI Studies Repository. For more information,

please contact

wbisr-info@wellbeingintl.org.

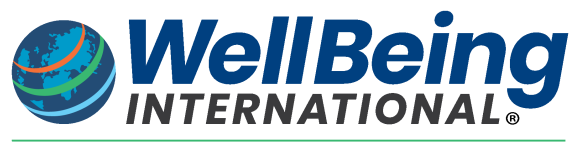

SOLUTIONS FOR PEOPLE, ANIMALS AND ENVIRONMENT 


\title{
If it looks like a duck: Fish fit the criteria for pain perception
}

\author{
Commentary on Sneddon et al. on Sentience Denial
}

\author{
Julia E. Meyers-Manor \\ Department of Psychology \\ Ripon College
}

\begin{abstract}
Whereas we have denied the experience of pain to animals, including human babies, the evidence is becoming clearer that animals across a variety of species have the capacity to feel pain (Bellieni, 2012). As converging findings are collected from pain studies and the study of cognition, it is becoming harder to deny that fish are among the species that do feel pain.
\end{abstract}

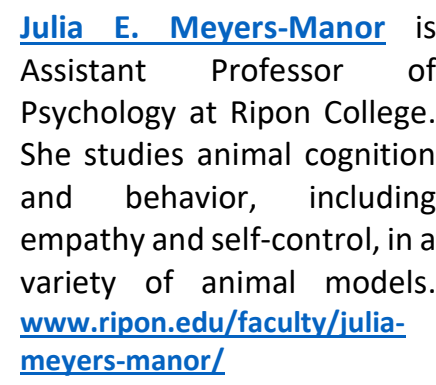

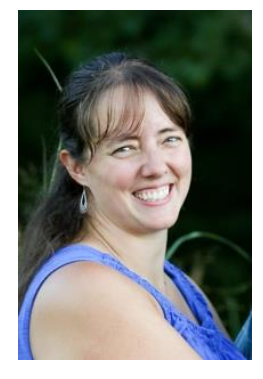

Until very recently, it was widely believed that infants and young babies were incapable of feeling pain (Bellieni, 2012). As with fish, the argument went that babies had the pain receptors but that they did not experience the pain due to an underdeveloped central nervous system and poor memory (Bellieni, 2012). However, the evidence is becoming clearer that babies have fully developed neurobiological systems to respond to pain (Fitzgerald \& Mclntosh, 1989) and that their behavioral responses are indicative of the experience of pain (Bellieni, 2012). The arguments for pain experiences in human babies are very similar to the criteria suggested by Bateson (1991) to test for pain in animals.

Specifically, Bateson (1991) and Smith and Boyd (1991) have three basic behavioral signals that indicate their perception of pain: (1) that they respond to painful stimuli in ways that reduce damage, (2) that these behaviors are altered by known analgesics, and (3) that animals engage in avoidance responses to minimize contact with noxious stimuli. In their target article, Sneddon et al. (2018) describe clear examples of increased motor behavior in fish experiencing acetic acid, which would normally be an adaptive response for removal from an environment. Further, they review support for the effectiveness of analgesics in suppressing this change in behavior. Other studies have shown extensive learning of avoidance responses to noxious stimuli in fish (e.g., Dunlop, Millsopp, \& Laming, 2006; Overmier \& Hollis, 1990; Overmier \& Hollis, 1983).

Thus, with good evidence that fish meet the behavioral criteria for the experience of pain, the sticking point on whether fish feel pain seems to be primarily a question of fish sentience. As described by Sneddon et al., sentience includes both cognitive and emotional abilities in animals. Chandroo, Duncan, and Moccia (2004) argue fish show representations of both their internal and 
external environments. For example, fish form cognitive representations of aversive stimulation and form expectancies about that stimulation (reviewed in Overmier \& Hollis, 1990). Fish show the ability to represent simple categories in order to form basic concepts such as musical types (Chase, 2001). They even show evidence of complex social skills such as social learning, cooperation, and cheating (as reviewed in Bshary, Wickler, \& Fricke, 2002).

It is not surprising that fish are capable of a variety of cognitively complex behaviors given the recent research suggesting that even many invertebrates show remarkable cognitive abilities. Bees show the ability to represent numbers (Gross et al., 2009). They also show evidence of problem solving in a string-pulling task and of the ability to transmit that learning socially (Alem et al., 2016). Similarly, jumping spiders show the ability to make decisions about the best routes to take to reach prey items (Tarsitano \& Jackson, 1997) and show expectancy violations based on the number of prey species present (Cross \& Jackson, 2017). Although it seems unlikely that we will ever find evidence of fish theory of mind or metacognition, it is hard to deny that a variety of animals across phyla seem to show the basic properties of what some authors call "primary sentience," the awareness of their internal and external environments (for review see Chandroo et al., 2004). As we once did with babies, we now seem to be making complex arguments to deny the experience of pain in fish. If a fish looks like she is in pain and acts like she is in pain, the likelihood is the fish is in pain.

\section{References}

Alem, S., Perry, C. J., Zhu, X., Loukola, O. J., Ingraham, T., Søvik, E., \& Chittka, L. (2016). Associative mechanisms allow for social learning and cultural transmission of string pulling in an insect. PLOS Biology, 14(10): e1002564.

Bateson, P. (1991). Assessment of pain in animals. Animal Behaviour, 42: 827-839.

Bellieni, C. V. (2012). Pain assessment in human fetus and infants. The AAPS Journal, 14(3): 456-461.

Bshary, R., Wickler, W., \& Fricke, H. (2002). Fish cognition: A primate' s eye view. Animal Cognition, 5(1): 1-13.

Chandroo, K. P., Duncan, I. J. H., \& Moccia, R. D. (2004). Can fish suffer?: Perspectives on sentience, pain, fear and stress. Applied Animal Behaviour Science, 86(3-4): 225-250.

Chase, A. R. (2001). Music discriminations by carp (Cyprinus carpio). Animal Learning \& Behavior, 29(4): 336-353.

Cross, F. R., \& Jackson, R. R. (2017). Representation of different exact numbers of prey by a spider-eating predator. Interface Focus, 7(3): 20160035.

Dunlop, R., Millsopp, S., \& Laming, P. (2006). Avoidance learning in goldfish (Carassius auratus) and trout (Oncorhynchus mykiss) and implications for pain perception. Applied Animal Behaviour Science, 97(2-4): 255-271.

Fitzgerald, M., \& McIntosh, N. (1989). Pain and analgesia in the newborn. Archives of Disease in Childhood, 64(4 SPEC NO.): 441-443.

Gross, H. J., Pahl, M., Si, A., Zhu, H., Tautz, J., \& Zhang, S. (2009). Number-based visual generalisation in the honeybee. PLOS ONE, 4(1): e4263.

Overmier, J. B., \& Hollis, K. (1983). The teleostean telencephalon and learning. In R. E. Davis \& 
R. G. Northcutt (Eds.), Fish neurobiology Vol.2: Higher brain areas and functions (pp. 265284). Ann Arbor: University of Michigan Press.

Overmier, J. B., \& Hollis, K. (1990). Fish in the think tank: Learning memory and integrated behaviour. In R. P. Kesner \& D. S. Olson (Eds.), Neurobiology of comparative cognition (pp. 205-236). Hillsdales, NJ: Lawrence Erlbaum.

Smith, J. A., \& Boyd, K. M. (1991). In J. A. Smith \& K. M. Boyd (Eds.), Lives in the balance: The ethics of using animals in biomedical research. Oxford: Oxford University Press.

Sneddon, L. U., Lopez-Luna, J., Wolfenden, D. C. C., Leach, M. C., Valentim, A. M., Steenbergen, P. J., Bardine, N., Currie, A. D., Broom, D. M., \& Brown, C. (2018). Fish sentience denial: Muddying the waters. Animal Sentience 21(1).

Tarsitano, M. S., \& Jackson, R. R. (1997). Araneophagic jumping spiders discriminate between detour routes that do and do not lead to prey. Animal Behaviour, 53(2): 257-266. 


\section{UQÀM/ISC Cognitive Science Summer School June 26 - July 6 2018, Montreal, Canada}

\section{The Other Minds Problem: Animal Sentience and Cognition}

Overview. Since Descartes, philosophers know there is no way to know for sure what - or whether others feel (not even if they tell you). Science, however, is not about certainty but about probability and evidence. The 7.5 billion individual members of the human species can tell us what they are feeling. But there are 9 million other species on the planet (20 quintillion individuals), from elephants to jellyfish, with which humans share biological and cognitive ancestry, but not one other species can speak: Which of them can feel - and what do they feel? Their human spokespersons - the comparative psychologists, ethologists, evolutionists, and cognitive neurobiologists who are the world's leading experts in "mindreading" other species - will provide a sweeping panorama of what it feels like to be an elephant, ape, whale, cow, pig, dog, bat, chicken, fish, lizard, lobster, snail: This growing body of facts about nonhuman sentience has profound implications not only for our understanding of human cognition, but for our treatment of other sentient species.

Gregory Berns: Decoding the Dog's Mind with Awake Neuroimaging

Gordon Burghardt: Probing the Umwelt of Reptiles Jon Sakata: Audience Effects on Communication Signals PANEL: Reptiles, Birds and Mammals

WORKSHOP: Kristin Andrews: The "Other" Problems:

Mind, Behavior, and Agency

Sarah Brosnan: How Do Primates Feel About Their Social

Partners?

Alexander Ophir: The Cognitive Ecology of Monogamy

Michael Hendricks: Integrating Action and Perception in a

Small Nervous System

PANEL: Primates, Voles and Worms

WORKSHOP: Jonathan Birch: Animal Sentience and the

Precautionary Principle

Malcolm MacIver: How Sentience Changed After Fish

Invaded Land 385 Million Years Ago

Sarah Woolley: Neural Mechanisms of Preference in Female Songbird

Simon Reader: Animal Social Learning: Implications for

Understanding Others

PANEL: Sea to Land to Air

WORKSHOP: Steven M. Wise: Nonhuman Personhood

Tomoko Ohyama: Action Selection in a Small Brain

(Drosophila Maggot)

Mike Ryan: "Crazy Love": Nonlinearity and Irrationality in Mate Choice

Louis Lefebvre: Animal Innovation: From Ecology to

Neurotransmitters

PANEL: Maggots, Frogs and Birds: Flexibility Evolving

SPECIAL EVENT: Mario Cyr: Polar Bears

Colin Chapman: Why Do We Want to Think People Are

Different?

Vladimir Pradosudov: Chickadee Spatial Cognition

Jonathan Balcombe: The Sentient World of Fishes

PANEL: Similarities and Differences

WORKSHOP (part 1): Gary Comstock: A Cow's Concept of

Her Future
WORKSHOP (part 2): Jean-Jacques Kona-Boun: Physical and Mental Risks to Cattle and Horses in Rodeos

Joshua Plotnik: Thoughtful Trunks: Application of Elephant Cognition for Elephant Conservation

Lori Marino: Who Are Dolphins?

PANEL: Mammals All, Great and Small

Larry Young: The Neurobiology of Social Bonding, Empathy and Social Loss in Monogamous Voles

WORKSHOP: Lori Marino: The Inconvenient Truth About Thinking Chickens

Andrew Adamatzky: Slime Mould: Cognition Through

Computation

Frantisek Baluska \& Stefano Mancuso: What a Plant Knows

and Perceives

Arthur Reber: A Novel Theory of the Origin of Mind:

Conversations With a Caterpillar and a Bacterium

PANEL: Microbes, Molds and Plants

WORKSHOP: Suzanne Held \& Michael Mendl: Pig

Cognition and Why It Matters

James Simmons: What Is It Like To Be A Bat?

Debbie Kelly: Spatial Cognition in Food-Storing

Steve Phelps: Social Cognition Across Species

PANEL

WORKSHOP: To be announced

Lars Chittka: The Mind of the Bee

Reuven Dukas: Insect Emotions: Mechanisms and

Evolutionary Biology

Adam Shriver: Do Human Lesion Studies Tell Us the Cortex is Required for Pain Experiences?

PANEL

WORKSHOP: Delcianna Winders: Nonhuman Animals in

Sport and Entertainment

Carel ten Cate: Avian Capacity for Categorization and

Abstraction

Jennifer Mather: Do Squid Have a Sense of Self?

Steve Chang: Neurobiology of Monkeys Thinking About

Other Monkeys

PANEL WORKSHOP: The Legal Status of Sentient

Nonhuman Species 